\title{
Structural evaluation of Ikhwatun shelter building constructed on liquefaction potential area in Padang city, Indonesia
}

\author{
Fauzan $^{1 *}$, Abdul Hakam ${ }^{1}$, Rina Yuliet $^{1}$, and Jonathan Vincensius Osman ${ }^{1}$ \\ ${ }^{1}$ Departement of Civil Engineering, Universitas Andalas, Padang, Indonesia
}

\begin{abstract}
Indonesia has often experienced seismic natural disasters such as earthquakes and tsunamis especially Padang City, the capital city of West Sumatera, Indonesia. In order to face the future earthquake and tsunami disaster, the local government has built a number of vertical evacuation shelters. One of the shelters is Ikhwatun shelter building located in Koto Tangah Subdistrict of the Padang City. The shelter was built near to the coastal and expected has liquefaction potential. This study is conducted in order to evaluate the shelter to restrain the earthquake and tsunami loads. The building is made of the reinforced concrete structure with the floor area of $2680 \mathrm{~m}^{2}$ and the high of $22.78 \mathrm{~m}$. Based on the result of the soil evaluation, it was found that the soil deposit in the shelter has high liquefaction potential. Therefore, the upper and lower structures are analyzed using special response spectrum of the earthquake loads for soil liquefaction, which is 1.5 higher than those on the non-soil liquefaction. The analysis result shows that the beams, columns, and foundations are all not able to resist the applied tsunami loads. It is suggested that the building to be strengthened before being used as a vertical evacuation shelter.
\end{abstract}

\section{Introduction}

Recently, Indonesia has experienced big seismic triggered disasters regarding earthquakes and tsunamis. The geographical location of Indonesia on the three main plates of the world is the main reason for the disasters. These plates become the resources of seismic activities that sometimes generate tsunamis.

In 2009, Padang, the capital city of the West Sumatra province, Indonesia, has experienced a big earthquake which caused damage to the buildings and infrastructures. The Padang City is also located on the West Coast of Sumatra Island, which wide open to the sea (Indian Ocean) where the active two-plate zone exists. This condition results in Padang City become one of the most earthquake and tsunami prone area. After the 2009 Sumatera earthquake, the government started establishing vertical evacuation shelters in Padang. One of the shelters is the Ikhwatun shelter building, located in Koto Tangah Subdistrict of Padang.

${ }^{*}$ Corresponding author: fauzanrn@yahoo.com 
Generally, the sand sediments near to the coastal area in Padang have the liquefaction potential. During the earthquake of September $30^{\text {th }}, 2009$, the liquefaction phenomena have occurred in Padang which caused the lateral movement, and sand boils as well as the landslides on the embankments [1].

Tsunami shelters are usually built in residential areas near the coastline, where the communities around the shelter can reach easily. The collapsed shelter clearly cannot be used as a post-earthquake shelter. Therefore, it is necessary to evaluate the existing shelter to ensure that the shelter can resist the earthquake, liquefaction, and tsunami.

\section{Evaluation of soil liquefaction potential}

Liquefaction is a natural phenomenon that occurs due to seismic shock. If the liquefaction happens, the increased water pressure in soil mass may reduce the soil strength. The liquefaction potential at Ikhwatun Shelter is assessed based on the relative density (Dr) and grain (D50) method [2]. The soil data was obtained from the samples, which is taken from the depth of 1.55-2.00 m with an N-SPT value of 23. The corrected N-SPT (N') value [3] is 19. The relative density value (Dr) is then estimated using Table 1 . This value is obtained by interpolating the corrected N-SPT value gave the Dr of 0.485 (48.5\%). Fig. 1 shows the sieve analysis data of the sample. Based on this figure, it is obtained the D50 of $0.36 \mathrm{~mm}$.

Table 1. The empirical value for $\phi$, and the volume weight of non-cohesive/ grained soil based on SPT-N correction value (N') [4]

\begin{tabular}{|c|c|c|c|c|c|}
\hline Compactness & Very Loose & Loose & Medium & Dense & Very Dense \\
\hline Relative Density, Dr (\%) & $0-0.15$ & $0.15-0.35$ & $0.35-0.65$ & $0.65-0.85$ & $0.85-1.00$ \\
\hline SPTN-value & $0-4$ & $4-10$ & $10-30$ & $30=50$ & $>50$ \\
\hline Angle of Internal Friction & $25-30$ & $27-32$ & $30-35$ & $35-40$ & $38-43$ \\
\hline Unit Weight (moist) & $11.0-15.7$ & $14.1-18.1$ & $17.3-20.4$ & $17.3-22$ & $20.4-23.6$ \\
\hline
\end{tabular}

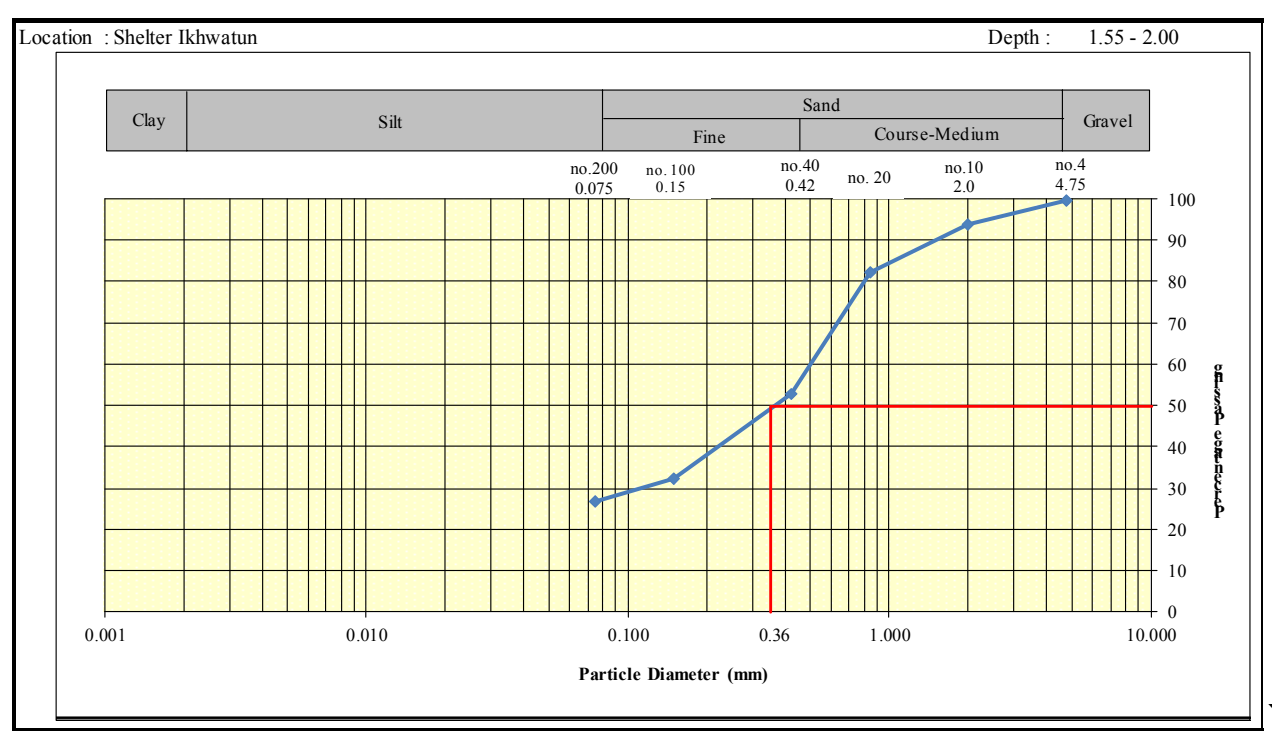

Fig. 1. Grain size distribution graph of D50. 


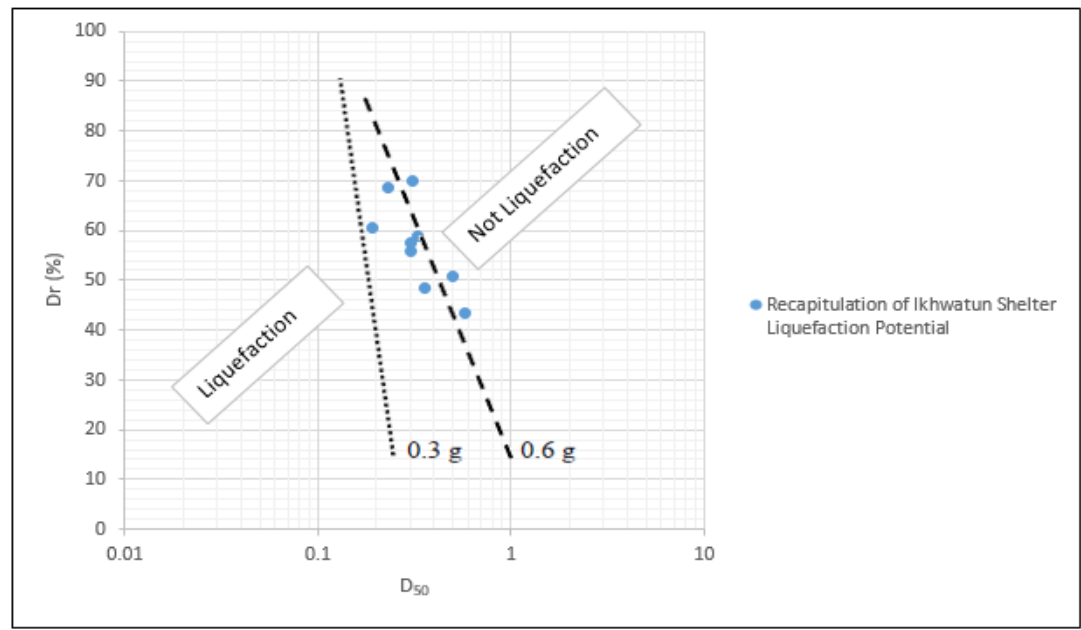

Fig. 2. Graph of liquefaction potential based on Dr and D50.

Table 2. Calculation results of Ikhwatun shelter liquefaction potential.

\begin{tabular}{|c|c|c|c|c|c|c|c|}
\hline No & Depth & $\mathbf{N}$ & $\mathbf{N}^{\prime}$ & D50 & $\begin{array}{l}\text { Dr } \\
(\%)\end{array}$ & Type of soil & $\begin{array}{l}\text { Liquefaction } \\
\text { potential }\end{array}$ \\
\hline 1 & $1.55-2.00$ & 23 & 19 & 0.36 & 48.5 & Silty Sand & Liquefaction \\
\hline 2 & $3.55-4.00$ & 16 & 15.5 & 0.58 & 43.25 & Well-graded sand & Not Liquefaction \\
\hline 3 & $5.55-6.00$ & 26 & 20.5 & 0.5 & 50.75 & Well-graded sand with silt & Not Liquefaction \\
\hline 4 & $7.55-8.00$ & 33 & 24 & 0.3 & 56 & Well-graded sand with silt & Liquefaction \\
\hline 5 & $9.55-10.00$ & 35 & 25 & 0.3 & 57.5 & Well-graded sand with silt & Liquefaction \\
\hline 6 & $11.55-12.00$ & 37 & 26 & 0.33 & 59 & Well-graded sand & Liquefaction \\
\hline 7 & $13.55-14.00$ & 6 & & 0 & 21.67 & Silt & - \\
\hline 8 & $15.55-16.00$ & 9 & & 0 & 31.67 & Silt & - \\
\hline 9 & $17.55-18.00$ & 16 & 15.5 & 0 & 43.25 & Silt with Sand & - \\
\hline 10 & $19.55-20.00$ & 27 & 21 & 0 & 51.5 & Silt with Sand & - \\
\hline 11 & $21.55-22.00$ & 32 & 23.5 & 0 & 55.15 & Silt with Sand & - \\
\hline 12 & $23.55-24.00$ & 35 & 25 & 0 & 57.5 & Silt with sand & - \\
\hline 13 & $25.55-26.00$ & 39 & 27 & 0.19 & 60.5 & Silty sand & Liquefaction \\
\hline 14 & $27.55-28.00$ & 52 & 33.5 & 0.23 & 68.5 & Silty sand & Liquefaction \\
\hline 15 & $29.55-30.00$ & 55 & 35 & 0.31 & 70 & Well-graded sand with silt & Not Liquefaction \\
\hline
\end{tabular}

The relative density (Dr) and the grain size distribution (D50) values are plotted into the liquefaction potential graph, as shown in Fig. 2. From the figure, it can be seen that the 
values mainly on the right of the $0.3 \mathrm{~g}$ lines and the left of the $0.6 \mathrm{~g}$ line. It means that the soil will experience liquefaction when the $0.6 \mathrm{~g}$ earthquake occurs. Table 2 shows the liquefaction assessment results of soil layers on this shelter. The ground of shelter building can be concluded as high liquefaction potential.

\section{Evaluation of building structure}

\subsection{Structure data}

The location of this shelter is close to the coastline, with a distance of $0.56 \mathrm{~km}$ from the Padang beach line. Based on the tsunami hazard map of Padang City, the depth of tsunami inundation in the location of the plan is about 4 to $5 \mathrm{~m}$ [5]. The tsunami inundation depth is based on the contours and tsunami wave prediction in Padang City.

The structural analysis of shelter building is modeled and analyzed using ETABS 9.7.1 software with linear analysis. The columns and beams of the building structure are shaped as frames. Meanwhile, the floor plates are modeled as slab elements. This 5-floor structure is made of reinforced concrete with the concrete compressive strength, $\mathrm{f}_{\mathrm{c}}$ ' of $30 \mathrm{MPa}$ and steel yield strength, $\mathrm{f}_{\mathrm{y}}$ of $400 \mathrm{MPa}$. The building height is $7.82 \mathrm{~m}$ for the $1^{\text {st }}$ floor and 3.74 $\mathrm{m}$ for $2^{\text {nd }}, 3^{\text {rd }}, 4^{\text {th }}$, and $5^{\text {th }}$ floors. The shelter area is $2680 \mathrm{~m}^{2}$ with the thickness of the slab of $15 \mathrm{~cm}$. Fig. 3 shows the 3D modeling of the shelter building.
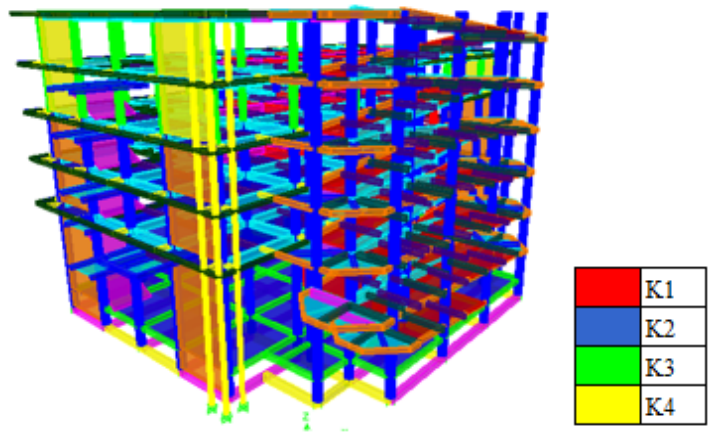

Fig. 3. Modeling of existing structure.

\subsection{Loads}

The dead and live loads refer to Minimum loads for Building Design and Other Structures of SNI 1727-2013 [6]. The analysis of earthquake load using dynamic analysis (earthquake response spectrum) for Padang City based on SNI 03-1726-2012 and earthquake map of 2017 by making its design of response spectrum. According to Article 5.3, Table 3 SNI 031726-2012 or Table 53 SNI 8460-2017, the value of N-SPT of medium soil ranges from 15 to $50[7,8]$. The N-SPT value of the shelter in the middle ground (SD) is 20.5 .

However, the soil at that location has the potential for liquefaction, so it is categorized as special soil (SF) according to Table 3 SNI 03-1726-2012 or Table 53 SNI 8460-2017. Furthermore, to calculate the response spectrum of a special soil (SF), it must follow the article 6.8 or 6.10 .1 in SNI 03-1726-2012, which stated that if the spectrum of the maximum-risk-targeted seismic response (MCER) is required, the design response spectrum then should be multiplied by 1.5. Therefore, the design spectral acceleration parameter values for moderate soil, SD1 obtained is 0.6, and the SDS is one were increased by 1.5 , so the value of SD1 and SDS will be 0.9 and 1.5 , respectively $[7,8]$. The result of the response spectrum calculation is plotted in Fig. 4. 


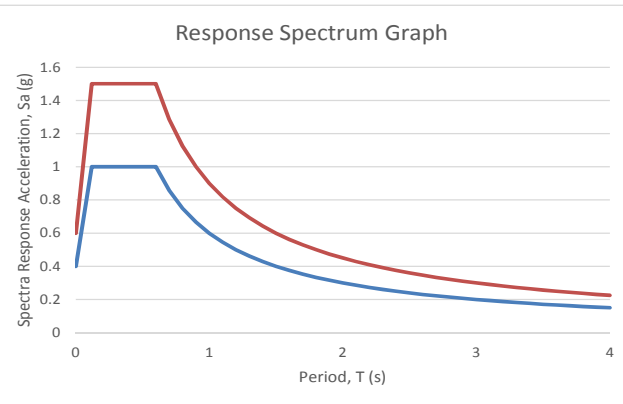

Fig. 4. SD and SF response spectrums.

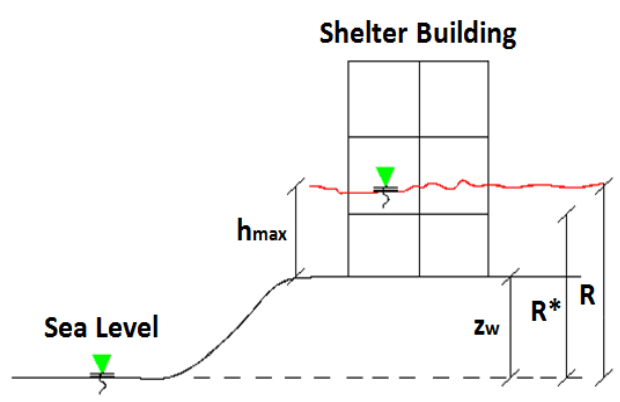

Fig. 5. Inundation of the tsunami plan.

Based on the FEMA P-646 [9], the refugee live load was taken $250 \mathrm{~kg} / \mathrm{m}^{2}$ on evacuation room. The tsunami loads are also calculated based on the FEMA P-646 Code 2012 [9]. The value of each load calculated based on the predicted wave height of the tsunami, the ground elevation of the shelter area, the distance from the shore and other assumptions used, which can be seen in Fig. 5. Table 3 shows the tsunami loads calculation applied to the shelter.

Table 3. Tsunami loads calculation.

\begin{tabular}{|c|c|}
\hline Tsunami load & Force (kg) \\
\hline Fh Hydrostatic force & -20516.65 \\
\hline Fd Hydrodynamic force & -5719.4 \\
\hline Fs Impulsive force & -8579.05 \\
\hline Fl Impact & -52119.13 \\
\hline
\end{tabular}

\subsection{Capacity of structure elements}

\subsubsection{Column capacity}

P-M interaction diagram is a diagram illustrating the ability or capacity of the column based on the relationship between the moment and axial load of the column.

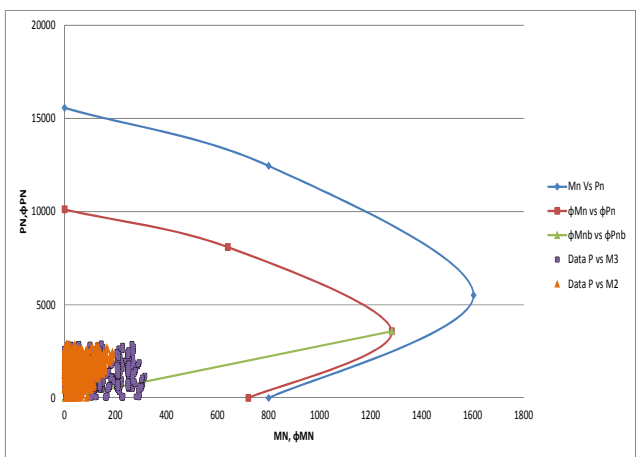

Fig. 6. P-M Interaction diagram of column $\mathrm{K} 1(\varnothing 70 \mathrm{~cm})$ at $1^{\text {st }}$ floor (Interior)

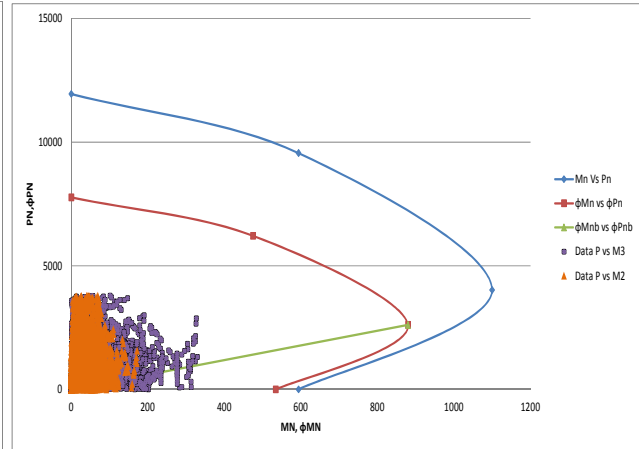

Fig. 7. P-M Interaction diagram of column $\mathrm{K} 2(\varnothing 60 \mathrm{~cm})$ at $1^{\text {st }}$ floor (Exterior) 


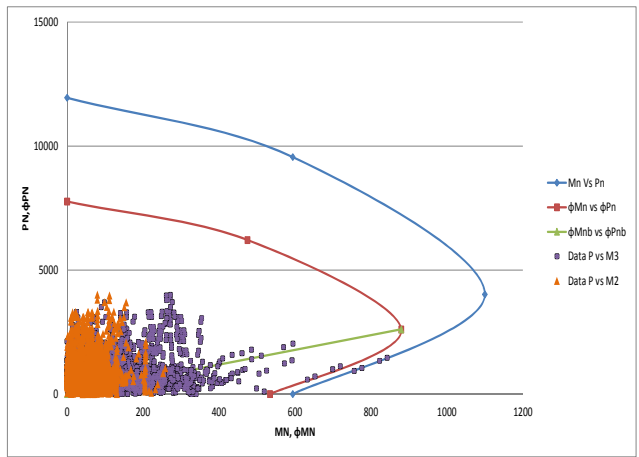

Fig. 8. P-M Interaction diagram of column $\mathrm{K} 2(\varnothing 60 \mathrm{~cm})$ at $1^{\text {st }}$ floor (Interior)

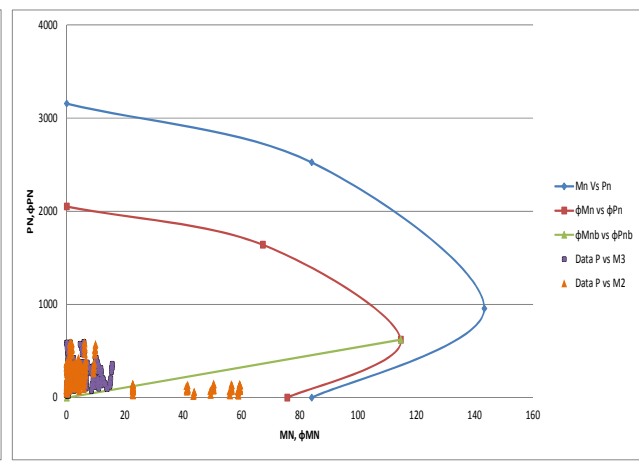

Fig. 9. P-M Interaction diagram of column $\mathrm{K} 4(\varnothing 30 \mathrm{~cm})$ at $1^{\text {st }}$ floor (Exterior)

Fig. 6-9 show P-M interaction diagrams of columns obtained from the results of the structural analysis. Based on these figures, it can be seen that the bending capacity of the $1^{\text {st }}$ floor columns can resist applied loads, but the shear capacities on K2 column are not strong enough to withstand the applied loads, as seen in Table 4.

Tabel 4. Calulation results of column shear capacity.

\begin{tabular}{|c|c|c|c|c|c|c|c|}
\hline Floor & $\begin{array}{c}\text { Column } \\
\text { Code }\end{array}$ & $\begin{array}{l}\text { Dimension } \\
(\mathbf{c m})\end{array}$ & Note & Floor & $\begin{array}{c}\text { Column } \\
\text { Code }\end{array}$ & $\begin{array}{c}\text { Dimension } \\
(\mathbf{c m})\end{array}$ & Note \\
\hline \multirow{4}{*}{$\begin{array}{c}\text { Tie } \\
\text { Beam }\end{array}$} & K1 & $\varnothing 70$ & $\mathrm{OK}$ & \multirow{4}{*}{3} & K1 & $\varnothing 70$ & NOT OK \\
\hline & \multirow{2}{*}{ K2 } & \multirow{2}{*}{$\varnothing 60$} & OK & & \multirow{2}{*}{$\mathrm{K} 2$} & \multirow{2}{*}{$\varnothing 60$} & OK \\
\hline & & & OK & & & & NOT OK \\
\hline & K4 & $\varnothing 30$ & NOT OK & & K4 & $\varnothing 30$ & $\mathrm{OK}$ \\
\hline \multirow{4}{*}{1} & K1 & $\varnothing 70$ & $\mathrm{OK}$ & \multirow{5}{*}{4} & \multirow{2}{*}{ K2 } & \multirow{2}{*}{$\varnothing 60$} & OK \\
\hline & \multirow{2}{*}{ K2 } & \multirow{2}{*}{$\varnothing 60$} & NOT OK & & & & NOT OK \\
\hline & & & NOT OK & & \multirow{2}{*}{$\mathrm{K} 3$} & \multirow{2}{*}{$\varnothing 50$} & NOT OK \\
\hline & K4 & $\varnothing 30$ & $\mathrm{OK}$ & & & & $\mathrm{OK}$ \\
\hline \multirow{5}{*}{2} & K1 & $\varnothing 70$ & $\mathrm{OK}$ & & K4 & $\varnothing 30$ & $\mathrm{OK}$ \\
\hline & & & $\mathrm{OK}$ & \multirow{4}{*}{5} & & & $\mathrm{OK}$ \\
\hline & K2 & 860 & NOT OK & & $\mathrm{K} 2$ & $\varnothing 60$ & $\mathrm{OK}$ \\
\hline & \multirow[b]{2}{*}{ K4 } & \multirow[b]{2}{*}{$\varnothing 30$} & \multirow[b]{2}{*}{$\mathrm{OK}$} & & K3 & $\varnothing 50$ & $\mathrm{OK}$ \\
\hline & & & & & K4 & $\varnothing 30$ & $\mathrm{OK}$ \\
\hline
\end{tabular}

\subsubsection{Beam capacity}

Tables 5 and 6 show the results of bending and shear capacities of the beam. The bending beam capacity on the tie beam, first floor, and second floor cannot resist the applied loads. 
The shear capacity on all of the level is not strong enough to restrain the applied loads.

Table 5. Calculation results of beam bending capacity.

\begin{tabular}{|c|c|c|c|c|c|c|c|}
\hline \multirow[t]{2}{*}{ Floor } & \multirow{2}{*}{$\begin{array}{l}\text { Beam } \\
\text { Code }\end{array}$} & \multirow{2}{*}{$\begin{array}{l}\text { Dimension } \\
\text { (cm) }\end{array}$} & \multicolumn{2}{|c|}{ Reinforced bar } & \multirow{2}{*}{$\begin{array}{c}\varnothing \mathrm{Mn} \\
(\mathbf{k N m})\end{array}$} & \multirow{2}{*}{$\underset{(\mathbf{k N m})}{\mathbf{M u}}$} & \multirow[t]{2}{*}{ Note } \\
\hline & & & Tension & Compression & & & \\
\hline \multirow{2}{*}{$\begin{array}{c}\text { Tie } \\
\text { Beam } \\
0.00 \\
\end{array}$} & \multirow[t]{2}{*}{ S3 } & \multirow[t]{2}{*}{$20 \times 40$} & 3 D16 & $3 \mathrm{D} 16$ & 66.833 & 148.806 & NOT OK \\
\hline & & & $3 \mathrm{D} 16$ & 3 D16 & 87.082 & 148.806 & NOT OK \\
\hline \multirow[t]{6}{*}{1} & \multirow[t]{2}{*}{ B5 } & \multirow[t]{2}{*}{$25 \times 40$} & $5 \mathrm{D} 12$ & $2 \mathrm{D} 22$ & 219.182 & 267.232 & NOT OK \\
\hline & & & $2 \mathrm{D} 22$ & $5 \mathrm{D} 22$ & 219.182 & 251.449 & NOT OK \\
\hline & \multirow[t]{2}{*}{ B6 } & \multirow[t]{2}{*}{$25 \times 40$} & $5 \mathrm{D} 19$ & $2 \mathrm{D} 22$ & 147.673 & 136.224 & $\mathrm{OK}$ \\
\hline & & & 2 D19 & $5 \mathrm{D} 19$ & 147.673 & 178.137 & NOT OK \\
\hline & \multirow[t]{2}{*}{ BL-2 } & \multirow[t]{2}{*}{$20 \times 35$} & 3 D16 & 3 D16 & 57.200 & 87.138 & NOT OK \\
\hline & & & 3 D16 & 3 D16 & 57.200 & 44.489 & $\mathrm{OK}$ \\
\hline \multirow[t]{2}{*}{2} & \multirow[t]{2}{*}{ BA } & \multirow[t]{2}{*}{$25 \times 40$} & $3 \mathrm{D} 16$ & 3 D16 & 67.765 & 78.975 & NOT OK \\
\hline & & & $3 \mathrm{D} 16$ & 3 D16 & 67.765 & 69.799 & NOT OK \\
\hline
\end{tabular}

Table 6. Calculation results of beam shear capacity.

\begin{tabular}{|c|c|c|c|c|c|c|}
\hline Floor & Beam Code & Dimension (cm) & Shear Bar & $\operatorname{Vn}(\mathbf{k N})$ & $\mathbf{V u}(\mathbf{k N})$ & Note \\
\hline \multirow{4}{*}{1} & \multirow{2}{*}{ B2 } & \multirow{2}{*}{$35 \times 70$} & D13 - 125 & 426.867 & 513.519 & NOT OK \\
\hline & & & $\mathrm{D} 13-150$ & 516.274 & 256.759 & OK \\
\hline & \multirow{2}{*}{ B4 } & \multirow{2}{*}{$20 \times 30$} & $\varnothing 10-150$ & 84.823 & 151.652 & NOT OK \\
\hline & & & $\varnothing 10-200$ & 100.589 & 75.826 & OK \\
\hline \multirow{4}{*}{2} & \multirow{2}{*}{ B2 } & \multirow{2}{*}{$35 \times 70$} & D13 - 125 & 426.867 & 513.519 & NOT OK \\
\hline & & & $\mathrm{D} 13-150$ & 516.274 & 256.759 & OK \\
\hline & \multirow{2}{*}{ B4 } & \multirow{2}{*}{$20 \times 30$} & $\varnothing 10-150$ & 84.823 & 151.652 & NOT OK \\
\hline & & & $\varnothing 10-200$ & 100.589 & 75.826 & OK \\
\hline \multirow{2}{*}{3} & \multirow{2}{*}{ B4 } & \multirow{2}{*}{$20 \times 30$} & $\varnothing 10-150$ & 84.823 & 151.652 & NOT OK \\
\hline & & & $\varnothing 10-200$ & 100.589 & 75.826 & OK \\
\hline \multirow{2}{*}{4} & \multirow{2}{*}{ B2 } & \multirow{2}{*}{$35 \times 70$} & $\mathrm{D} 13-125$ & 426.867 & 514.499 & NOT OK \\
\hline & & & $\mathrm{D} 13-150$ & 516.274 & 257.250 & OK \\
\hline \multirow{4}{*}{5} & \multirow{2}{*}{ B4 } & \multirow{2}{*}{$20 \times 30$} & $\varnothing 10-150$ & 84.823 & 153.713 & NOT OK \\
\hline & & & $\varnothing 10-200$ & 100.589 & 76.856 & OK \\
\hline & \multirow{2}{*}{ B6 } & \multirow{2}{*}{$25 \times 40$} & D13 - 125 & 245.555 & 193.851 & OK \\
\hline & & & D13 - 150 & 259.774 & 96.926 & NOT OK \\
\hline
\end{tabular}




\subsubsection{Foundation capacity}

Based on SNI 8460-2017 of article 12.2.4.3, the friction resistance at the soil layer with liquefaction potential should be ignored for the pile foundation [8]. In the Ikhwatun shelter, the foundation type is pile with $350 \mathrm{~mm}$ diameter and $30 \mathrm{~m}$ depth and concrete strength, $\mathrm{f}_{\mathrm{c}}$, $=60 \mathrm{MPa}$. Fig. 10 shows the foundation plan of this shelter.

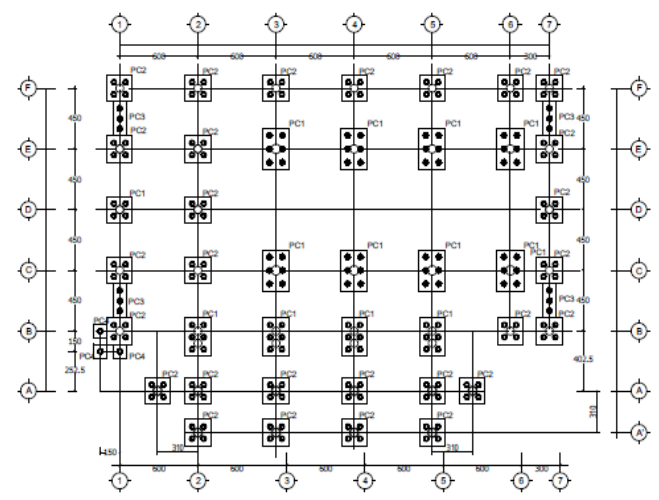

Fig. 10. Foundation plan.

The soil data was obtained from NSPT test results on the field and the results of the granular analysis in the laboratory [10]. Calculation of foundation capacity was carried out using the calculation of static axial pole capacity with SPT based on Mayerhof method [11].

Table 7. Calculation results of foundation bearing capacity

\begin{tabular}{|c|c|c|c|}
\hline $\begin{array}{c}\text { Type of } \\
\text { foundation }\end{array}$ & Qn (kN) & Qu (kN) & Note \\
\hline PC1 & 3487.207 & 3487.170 & OK \\
\hline PC2 & 2324.805 & 4851.900 & NOT OK \\
\hline PC3 & 1743.603 & 10110.740 & NOT OK \\
\hline PC4 & 581.201 & 601.760 & NOT OK \\
\hline
\end{tabular}

Based on the results of the foundation bearing capacity in Table 7, it can be seen that foundation PC2, PC3 and PC4 has not enough capacity to resist the applied loads.

\section{Conclusions}

The Ikhwatun shelter building has been built in a high potential of the soil liquefaction. The structural analysis then must consider the spatial condition of the soil as stated by the standard code. Based on the result of the structural analysis, the bending columns capacities can resist the working loads, but shear capacities of the columns may not be able to withstand the applied loads. The beams also have not strong enough capabilities to resist the working loads. Further, the result of the foundation analysis obtains that the capacity of pile foundations is unable to resist the applied loads, especially when the case of earthquake and liquefaction. Then, it is suggested that the shelter must be strengthened before being used as a vertical evacuation building for the earthquake and tsunami. 
The authors would like to acknowledge the funding support provided by Andalas University, Padang, Indonesia.

\section{References}

1. T.L. Youd, C.T. Garris, Jour. of Geotech. Eng. 121, 11 (1995)

2. A. Hakam, Proc. of Andalas Civil Engineering Seminar (2016)

3. R.R.I. Legrans, S. Imbar, J. of Tekno-Sipil 4, 56 (2011)

4. J. E. Bowles, Foundation analysis and design (McGraw Hill, Singapore, 1977)

5. Regional Development Planning Board of Padang City, Tsunami Hazard Map of Padang City year 2008-2028

6. Standar Nasional Indonesia, Minimum Loads for Building Design and Other Structures SNI 1727-2013 (Badan Standardisasi Nasional, Jakarta, 2013)

7. Standar Nasional Indonesia, Earthquake Resilience Planning Procedure for Building and Non-Building SNI 1726-2012 (Badan Standardisasi Nasional, Jakarta, 2012)

8. Standar Nasional Indonesia, Geotechnical Design Requirements SNI 8460-2017 (Badan Standardisasi Nasional, Jakarta, 2017)

9. FEMA, Guidelines for Design of Structure for Vertical Evacuation from Tsunami FEMA P646-2012 (Federal Emergency Management Agency, Washington DC, 2012)

10. Anonim. Road infrastructure, spatial planning, and settlement of west sumatera province, boring log data \& land filter analysis shelter ikhwatun report (UPTD Construction \& Environment Testing Center, Padang, 2018)

11. G.G. Mayerhof, Jour. of the Geotech. Eng. Div. 102, 3 (1976) 